\title{
Circumfixation: Interface of Morphology and Syntax in Igbo Derivational Morphology
}

\author{
B.M. Mbah \\ Department of Linguistics, Igbo and other Nigerian Languages, University of Nigeria, Nsukka
}

\begin{abstract}
This study is an attempt to describe circumfixation in the Igbo language. Its specific objectives include determining how circumfixation applies within and across lexical boundaries in the language. It tries to identify the types of circumfix in the language. It examines the tonal changes that occur in the process of circumfixation. The approach adopted in the study is morpho-syntactic. It shows how syntactic patterns are modifed to form morphological forms. The paper found out that circumfixation, contrary to popular view, is prevalent in the language. Furthermore, quite unlike in many languages where it has been reported to be highly irregular; it is to a large extent regular in Igbo. Tone plays an important role in the formation of words through circumfixation. After circumflection, the tone pattern of the root or stem is changed though the syllable structure of Igbo is retained. The discontinuous parts of the circumfix are each a syllable, one at the beginning and the other at the end of the root word. There are two types of circumflection in the language: the obligatory complement taking and the non-obligatory complement taking circumfixation. The non-obligatory complement taking circumfixation usually forms a free form, which can stand independently as any other lexical item of the language. On the contrary, in the obligatory complement taking circumfixation, the nature of the complement determines whether the discontinuous end of the circumfix is desyllabified or otherwise. If the following complement begins in a vowel, the circumfix loses the syllable status of the discontinuous end of the circumfix. It turns into a liaison thereby making the circumfix function as a bridge between the root word and the complement. The exception to this rule is in forming negatives. In the latter situation, a compound form is created while in the former two words in associative construction are recognised.
\end{abstract}

\section{Introduction}

An important characteristic of language is that it has the ability to generate lexical items from bits of sounds and morphemes. Morphology is the study of word formation in language. In morphology, there are two main processes of word formation, namely inflectional and derivational morphology. Derivational morphology is class changing whereas the result of inflectional morphology is non-class changing. In either of the genres of word formation, affixation is the device used in generating lexical items.

Circumfixation appears to be the least studied when compared to prefixation, infixation, interfixation, suffixation and suprafixation. Part of the reason is that circumfixation is not attested in many languages as the other types of affixation. Furthermore, scholars have not agreed on the status of circumfixation across languages. The phenomenon is still controversial (see Scalise, 1984). Schultink (1987) posits that it violates the constraint on binary branching because its elements occur at the beginning and end of the word which hosts it. Kayne (1994) lists the conditions on binary branching in a syntactic percolation, namely: it must be transitive, anti-symmetrical and total. On the other hand, Zwicky (1985) argues that the head of a morphosyntactic percolation bears the morphosyntactic locus. In other words, it is the place where the affixes are attached. Circumfixation does not observe these features. The two discontinuous parts of the circumfix cannot be independently hosted by any word without making the word unacceptable. It is in view of the above controversies and the insular nature of circumfixation that we elect to investigate it in Igbo. The Igbo language is an East Benue Congo language of the Niger Congo phylum spoken in South Eastern Nigeria.

\section{On Defining Circumfixation ${ }^{1}$}

Circumfixation is synonymous with ambifix or confix (Wiktionary (2011), circumflection or circumfix (neohumanism.org, 2011), and discontinuous or parasynthetic affix (Scalise, (1984) and Schultint (1987)). We will be using circmfixation because it is the most popular of the synonyms (see Anagbogu (1990), Anagbogu, Mbah \& Eme (2010), Fromkin (2003), Ihezuonu (2011). A synthesis of the definitions of these authors including wikipedia (2011), sil.org (2004), Boeckx \& Fumikazu (2004), Spencer (1991), Finegen (2004), Fromkin (2003) shows that circumfixation is a process in which a discontinuous affix comprising two dissimilar parts surround an otherwise free morpheme. The often cited English illustration is the dialect English example with the general pattern: $a$-...-ing as in a-going, $a$-coming. 


\section{Theoretical Background}

Ndimele (1999) defines an affix as a morpheme that is placed around another morpheme. Five types of affix are popular in literature: prefix, infix, interfix, circumfix and suprafix (see also Nida, 1949). Ndimele (1999) identifies two criteria for classifying affixes; they include the position of occurrence with respect to the root, and its function after affixation. The above types of affix are classified on the basis of their positions with respect to the root. The prefixes occur before the root; the infixes within a morpheme, the interfix between two identical morphemes or roots, the circumfix around the morpheme and the suprafix superimposed on the segments.

The type of root or stem that may host the circumfix varies from language to language. The circumfix has different grammatical functions in different languages. Spencer (1991) contends that Malay, an Indonesian language, has been elaborately reported as attesting circumfixation in its morphology. It has eight types of discontinuous affixes. They include:

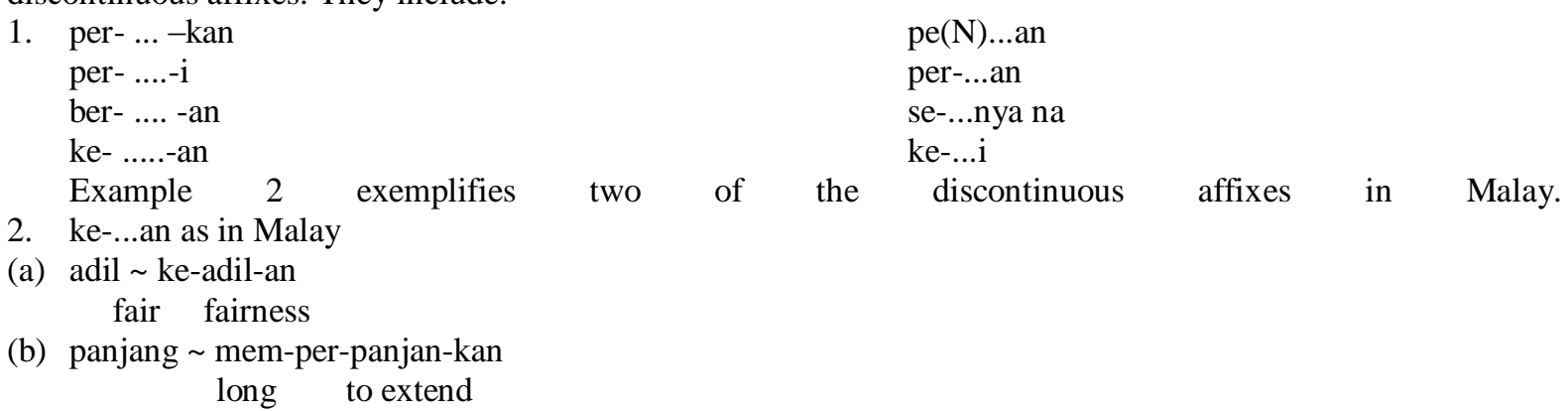

In example 2, the adjectives get changed to nouns after affixation. Evidence from the website, www.sil.org (2004), notes that in Malay, adverbs and adjectives may be used to derive verbs. In Malay, circumfixation is non-class maintaining. It obligatorily changes the original grammatical class of the root. Ihezuonu (2011) provides additional data from German and Dutch. Let us examine the following data:

3. ge-....-te as in Dutch

(a) berg ge-berg-te

mountain mountains

(b) vogel ge-vogel-te

bird poultry

(b) raam ge-raam-te

frame skeleton

In Dutch, circumfixation is a device used in the formation of plurality. Quite unlike in Malay, it is class maintaining. In other words, it does not change the grammatical class of the root word.

In Japanese, circumfixes exist. They are used for honorific distinction. Boeckx and Fumikazu (2004) give the following illustrative examples:

4. $\quad$ o-...-ni, o-...-suru as in:

yomi o-yomi ni neru "respectful"

o-yomi-suru "humble"

In 4 , circumfixation marks the different ways of showing honour and respect. o-...-ni marks a show of respect for the addressee while o-...-suru shows humility on the part of the speaker.

Fromkin (2003) demonstrates circumfixation with Chikasaw, a language spoken in Oklahoma. The examples include the following:

5. ik-....-o as in Chikasaw

(a) chokma Ik-chokm-o

He is good. He is'nt good

(b) lakna ik-lakn-o

It is yellow. It isn't yellow

(c)Palli ik-pall-o

It is hot. It isn't hot

(d)Tiwwi Ik-tiww-o

He open (it). He doesn't open (it)

culled from Ihezuonu (2011:5)

In examples 5, the application of circumfixal affixation has a consistent effect on the root word. It does away with the last vowel of the root word. For instance, in the example above, the first two examples end in low back vowels whereas the last two end in high front vowels, yet each of them lost its last vowel to the circumfixal vowel, which displaces and takes over the position. 
In some other languages such as Berber, circumfixation is used to indicate gender while in Guarani, it is a negator. In Tuwali Ifugoo, a Philippino language, circumfixation functions as a nominaliser. The circumfixes in the above language are $\mathrm{t}-. . .-\mathrm{t}$, nd-...-i and ka-...-an respectively.

From the above survey of literature on circumfixation, it could be understood that data on circumfixation are not profuse and the circumfix performs different grammatical functions in them.

\section{Circumfixation in Igbo}

The phenomenon of circumfixation is observable in the Igbo language. However, few scholars have recognised the phenomenon in the language. The first scholar that broached the subject matter in the language is Anagbogu (1990). He identifies it as one of the affixes. The next mention of it in literature is contained in Anagbogu, Mbah and Eme (2010). Like in Anagbogu (1990), it was not treated in detail. Ihezuonu (2011) is supposed to be a detailed analysis of circumfixation. However, she ends up reviewing literature on the subject without any insight into its type and morphosyntactic behaviour in the language.

Circumfixation in Igbo shares the universal characteristic of being discontinuous. It branches into two parts. In the Igbo circumfix, there is a head. We posit that the initial part of the affix is the head. It does not vary its morphological shape when it changes its position or when the host changes. The other part of the discontinuous circumfix may change its form or as we shall see in example 13; it is subject to vowel harmony. There are two types of circumfixation in the language: the vowel-syllabic nasal circumfix and the vowelincorporated preposition circumfix.

The distribution of the limbs of the circumfix marks it out from the other affixes. The prefixes come before the host, the interfixes within two identical parts of a word and the suffix after the word. It has been widely reported that in Igbo, it is only the verb that accepts inflection. That is why Nwachukwu (1983) has called Igbo a verb language. Let us eaxmine the following examples

6. (a) Òkéké gà-rà áhịa

Okeke gopast market - Okeke went to the market

(b) Òkéké à-gá- $\bar{a}$-lá áhịá

Okeke a-go-has market - Okeke has gone to the market

(c) ĺjè dèrè édé- $m$-édé

Ije writepast composition - Ije wrote a composition

In example 6, the italicised forms are affixes. In $6 a,-r a$ is a suffix because it occurs at the end of its host. In $6 b$, $a$ - is a prefix as it occurs before its host while $-a$ is an infix for being within unidentical parts of a word. In $6 c$, $m$ - is an interfix because it occurs between two identical parts of a word. As we shall see shortly, these positions differ from that of the circumfix, which forms the focus of our study.

\section{Vowel-syllabic Nasal Circumfix}

This type of circumfix is made up of an initial vowel and a syllabic nasal that is obligatorily a bilabial nasal [m]. Let us examine the following array of examples.

7. à m as in á
(a) àdịm being
(b) àgàm . going
(c) àzàṃ sweeping

$D i ̣$ (be), gá (go) and zà (sweep) are verb roots. The first two roots have an inherent high tone while the last one has an inherent low tone pattern. In the above examples, all the derived words have grammatical low tones. In other words, the circumfix compels the roots with inherent high tones to change them to low tones. This change affects the reading of the verb. For instance, there is a difference between the examples in 6 and the following construction types:

8. (a) Ádịm ... - Am I...?

(b) Àgà m ... - Will I...?

(c) Àz $\square$ ṃ- Did I sweep ...?

The examples in $8 \mathrm{a}-\mathrm{c}$ have the same letters and tone pattern as those in example 7 . The examples in 8 are interrogative constructions, which have meaning under established contexts. In 8, mis detached from the gerundives of 7; this detachment makes it function as the first person pronoun singular. As one can deduce from the meaning of 8 , the separation of $m$ from the verb complex changes the meaning of 7 altogether. Furthermore, when the tone of the first segment of example 7 is changed to a high tone, another syntactic pattern with a different meaning results:

9. (a) Ádịm ... - I am ...(I have the features of)

(b) Ágạm... - I will...

(c) Ázạm- I swept ... (Ịka dialect) 
The examples in 9 present the assertive forms of the examples in 8 . The examples in 7-9 show how differences in morphology and syntax bring about a whole world of semantic differences in the Igbo language. The tone pattern of 7 may also change to low high high:

10. á m $\square$ as in
(a) $\square \square \operatorname{sị} \square \mathrm{m} \square$ - possibility of talking
(b) $\square \square \square \square \square \square$ - possibility of eating
(c) $\square \square \square \square \square$ - possibility of answering

In 10 , the change of the tone pattern has affected the meaning. An interesting feature is that the verb roots consistently form a tonal paradigm irrespective of the inherent tone of the verb root. After the change of morphological form, the meaning of the circumfix does not change irrespective of the verb root that it is attached to. The change of meaning is as shown in the above rough equivalences of the English translation. Another possibility of tone is as shown in 11 .

11. á $\square$ as in
(a) ádị $\square m$ - not being
(b) ád $\square$ m - not warming
(c) ébu $\square$ m - not carrying

The tone of the circumfixes has changed to high down-step. The down-step tone is one of the patterns of the negator in the grammar of the language. As reasonably argued by Zwicky (1985), the head of a word is the locus where affixes get attached to; that is, the head of a word bears the affixes. In the above examples, the circumfixes form the morpho-syntactic loci which host the varying tones.

As one may deduce from the above examples, in spite of the addition of circumfixes to the root, the argument structure of the roots remains the same. The verbs are limited to the same complements that they select inherently. For instance, exanple 12 presents illustrations of circumfixation and complementation in the language.

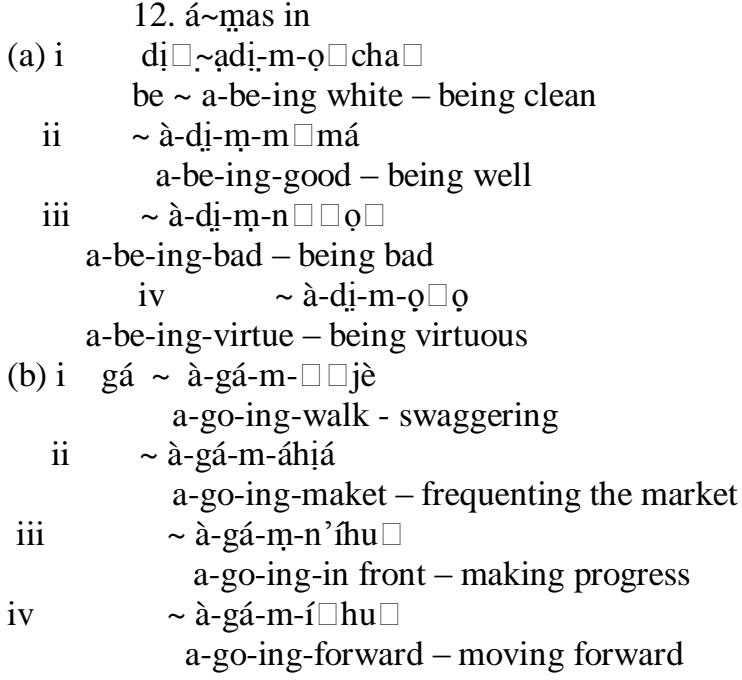

Prior to circumfixation, the nouns following the verbs serve as the inherent complements of the verbs such as $d i ̣ \square \square \square \square \square$ (be clean), dị $\square \square \square \square o \square$ (be bad), dị $\square m \square m a \square$ (be good), ga $\square i \square j e \square$ (walk), ga $\square a \square h i ̣ \square$ (go to the market) and g $a \square n^{\prime} i \square h u \square$ (move forward). In examples 12, the roots $d i ̣$ and g $a \square$ take circumfixes with some of their inherent complements. $D i \square$ is an inherently low tone verb whereas ga $\square$ is inherently high. They could be found in the following examples
$12^{1}$ a. A $\square$-gá-ṃ-n’íhu $\square$ dị mkpa na ndụ
Progress be important in life - Progress is important in life.
b. A-dì-ṃ-m $\square$ má ya dị ịtụnanya

Being well it be to throw in eye - It beauty is wonderful

After circumfixation, they change their inherent tones to low tone. They translate to new concepts in the language. In the following example, the tone pattern changes to form further new forms 13. à $\sim \mathrm{m} \square$ as in

$$
\begin{aligned}
& \text { a. ị. } \square \underline{i} \square \sim \square-d-i ̣ \text {-m-ọ } \square \text { ch } \square \\
& \text { be act of being clean }
\end{aligned}
$$




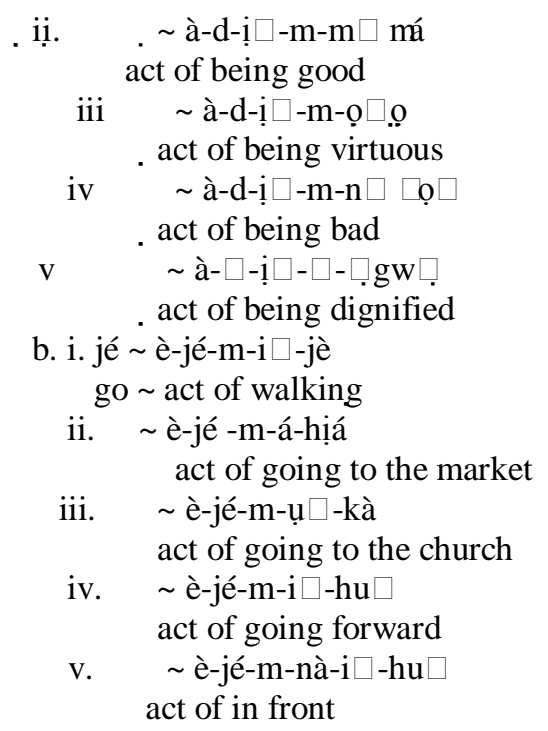

In examples 12 and 13, the change in the tone pattern of the circumfix has affected the meaning. This variation in the tone of the circumfix may apply to all the verb roots which can take them in the formation of words in the language. And a great majority of the verbs can; this is subject to the presence of the inherent verb complements, which they go with in the morpho-syntax of the language. The formation is further subject to the vowel harmony rule (refer to examples 12 and 13). The vowel of the verb root which is produced with advanced tongue root (+ATR) selects circumfixes that have the same features. Examples 13 are illustrative. On the hand, the vowels with retracted tongue root (-ATR) co-occur with circumfixes with harmonising features. This is shown by examples 12. These characteristics make circumfixation a common and productive morphological process in the language.

The tone of the circumfixation can change to high down-step to yield negative expressions. The following examples show the negative forms with the consequent semantic change:

14 á mas as in

$$
\begin{gathered}
\text { dị } \square \text { á-dị- } \square \text { mạ- ọ } \square \text { chá } \\
\text { be } \quad \text { not clean - not being clean } \\
\sim \text { á-dị } \square \text {-ṃ-m } \square \text { má } \\
\text { not being well } \\
\sim \text { á- dị } \square \text { - } \square \text {-n jọ } \square \\
\text { not being bad } \\
\text {. á- dị- } \square \text { mạ-ụgwụ } \\
\text { not being virtuous }
\end{gathered}
$$

(b) i. gá á-gá-ṃ-i $\square$ è

not being able to walk

ii. á-gá-ṃ- áhịá

not going to the market

iii. $\quad$ á-gá-ṃ-ná-i $\square$ hu $\square$

iv. $\quad$ not making pró-m-i $\square$ hu $\square$

not going forward

The right limb of the discontinuous affix negates the action of the phrase. The tone of - m- remains after affixation. This is unlike its tone pattern on the preceding examples, where the $-\mathrm{m}$ - is a liaison and does not bear tone when the following word starts in a vowel. Once the tone pattern is removed in example 14 such that it becomes a liaison, the resulting structure becomes unacceptable. The a m/e-m circumfix is about the most productive circumfix in the language. There are other circumfixes in the language. They include the following:

15. a. é $\sim$ m as inékwo $\square$ ṃ reliance

éri $\square$ m - candle

élém - moping at

b. i $\square \sim$ mas ịni $\square$ zịm (Nsukka dialect) - nose bleeding

c. $\mathrm{o} \square \sim \mathrm{m} \square$ as in $\underline{\mathrm{o}} \square$ bọ $\square \mathrm{m} \square$ - pavilion

ọdọm - reservoire 


$$
\begin{gathered}
\text { ojọ̣ } \square \mathrm{m} \square \text { - hater } \\
\text { odụm } \square \text {-lion } \\
\text { d. ụ } \sim \mathrm{m} \square \text { as in ụri } \square \mathrm{m} \square \text { - candle } \\
\text { ụriọm - chick } \\
\text { e. ụ } \sim \mathrm{m} \text { as in ụbịàm - abject poverty } \\
\text { ụjám } \square \text { - motivation } \\
\text { f. } \mathrm{m} \sim \mathrm{m} \text { as in ṃ̣èm - chant } \\
\text { ṃmèm - bonus } \\
\text { g. } \mathrm{n} \sim \mathrm{m} \text { as in ṇdẹm - solvency } \\
\text { ṇjèm -journey }
\end{gathered}
$$

The above examples try to show that each of the Igbo vowels and the syllabic nasals has, with the discontinuous nasal circumfix [m], the ability to form a circumfix in the language. All the eight vowels except i- and o- (with which we cannot find examples even though they may exist) can combine with $-\mathrm{m}$ to form circumfixes in the language. However, they are not as prolific as the a m circumfix.

\section{Morphology-Syntax Interface}

When the root has taken circumfixes and circumfixation has occurred, two morphological processes may take place. These processes have a direct relationship with the eventual outcome of the resulting derivation. The first process is that the root word and the complement may come together so that they are pronounced consecutively. In so doing, the second limb of the circumfix fuses with the initial syllable of the complement, breaks the juncture between the two and loses its status as a syllable. It is this characteristic that disables it from being the nucleus of the circumfix.

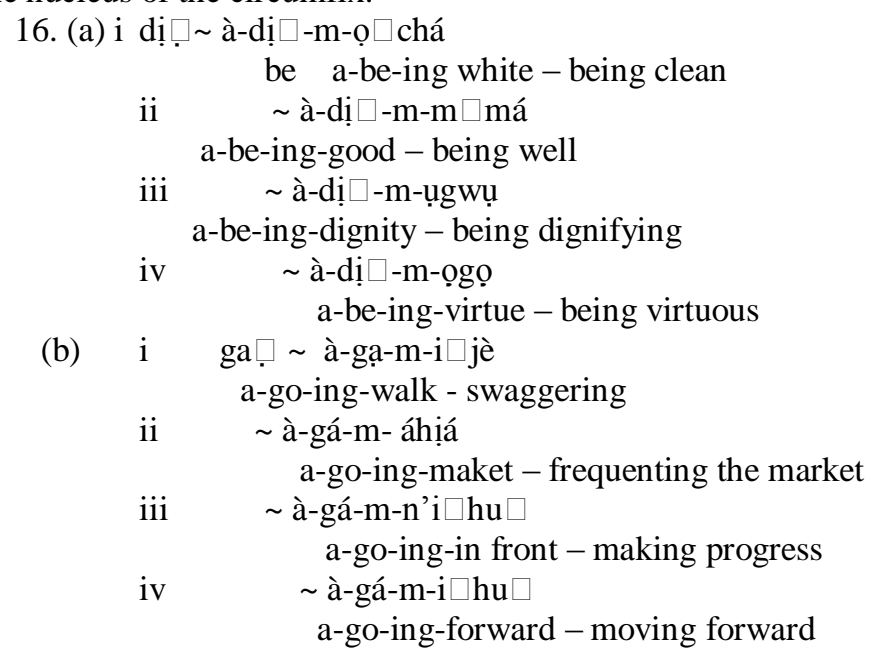

The above example shows where the complement starts with vowels and where they do not. In all the examples except adim mma, and agam n'ihu the complement starts with a vowel. This makes merger at the phonological level possible. It becomes possible to produce both of them as a single word. To do this, the syllabic nasal of the discontinuous circumfix loses its status as a syllabic nasal, fails to bear the peak of prominence of its syllable and becomes a liaison. This is enhanced by the fact that its tone and the tone of the first syllable of the complement are the same, which is, they have a high tone. This is not the case with complements starting with consonants. With this class of complements, two things happen, namely, either a vowel is introduced between the two syllabic nasals or the juncture is left between them. If the first alternative prevails, it maintains the form of those forms whose complements begin in vowels. Otherwise, they retain their status as independent words and form associative constructions, that is:
17. i a-dị-mụ-mma or a-dị-m mma
a-be-ing-good - being well
ii a-dị-mụ-ugwu or a-dị-m ugwu
a-be-ing-virtuous - being dignifying

(b) i. a-ga-mụ-n'ihu or a-ga-mụ n'ihu

a-go-ing-in front - making progress

Whether the vowel is introduced to connect the two words or the juncutre is broken, the meaning remains the same. 


\section{Syllable-Preposition Circumfix}

The other type of circumfix in the Igbo language is made up of an initial syllable and an $-\mathrm{rV}$ suffix, which as we shall see expresses prepositional notions. The following example shows some examples:

18. (a) à rijas in

(b) ṇ rụ $\square$ as in

$$
\begin{aligned}
& \text { sị } \square \text { à-si-rị } \\
& \text { say gossip }
\end{aligned}
$$

(c) $\mathrm{i} \sim \mathrm{ri} \square$ as in

$$
\begin{aligned}
& \text { gụ } \square \sim \text { n-gụ } \square \text {-rụ } \square \\
& \text { pick pick }
\end{aligned}
$$

$$
\mathrm{ti} \square \sim \mathrm{i} \text {-ti } \square \text {-ri } \square
$$

beat darkness

(d) $\underline{\varphi} \sim \dot{i} \square$ as in

$$
\text { dị } \square \sim \text { ụ-dị } \square \text {-rị } \square
$$

be - type

(e) $\underline{m \sim r u ̣} \square$ as in

$$
\begin{aligned}
& \text { mụ } \square \sim \text { m-mụ } \square \text {-rụ } \square \\
& \text { give birth to - bearing for }
\end{aligned}
$$

The examples in 18 are made up of an initial syllable, which is either a vowel or a syllabic nasal. Furthermore, the discontinuous - $\mathrm{rV}$ circumfix is made up of $-\mathrm{r}$ - and a vowel which is determined by the harmonic vowel of the root. The contextual meaning of the $-\mathrm{rV}$ is equivalent to the English for or to. The tone pattern of the inceptive syllable of the circumfix in 18 is consistently low. On the other hand, the discontinuous circumfix does not have a stable tone pattern. In example 18, the first derived word ends in low tone whereas the other ones end in high tones.

The syllable $\sim$ preposition type of circumfix does not require an obligatory complement to express a full meaning.

\section{Summary of Findings and Conclusion}

This study of circumfixation in the Igbo language has revealed that circumfixation is pervasive in the language even though it has hardly been reported. Generally, it applies within verbal roots. It is consistent with Igbo morphology in which only the verb accepts inflection. Like similar circumfixes in other languages, it applies in a discontinuous manner; two dissimilar parts get affixed to the beginning and end of an otherwise free form. In Igbo, the first segment comprises a vowel or syllabic nasal while the second discontinuous segment is the bilabial nasal [m] which is syllabic in the language. The other type has an initial vowel or a syllabic nasal and an $-\mathrm{rV}$ discontinuous circumfix. The former type of circumfixation does not obligatorily take a complement to express a full meaning. The latter type does not require an obligatory complement to express a full lexical meaning.

Circumfixation does not form closed syllables in the language. The structure makes compounding possible (refer to example 17-18). In any case, convention appears to have limited compounding to circumfixes ending only in the syllabic nasal. Circumfixation, which ends in forms other than the syllabic nasal is separated orthographically from the complement, which follows it. This type of circumfixation forms nominals. The circumfixation, which ends in a syllabic nasal is regular in behaviour and form whereas the type ending in $-\mathrm{rV}$ does not have tonal or segmental regularity.

\section{Note}

1. We are aware that Scalise (1984) has discredited the term and made its study controversial. With Schultint (1987), he argues that circumfixation can be reduced to suffixation and its concomitant prefixes. Furthermore, Schultint (1987) argues that it violates the binary branching constraint. There is a proliferation of terms in an attempt to properly characterise the phenomenon. However, there is yet no better option.

\section{References}

[1] Anagbogu, P.N. (1990). The Grammar of Igbo Nominalisations. Onitsha, Nigeria: Varsity Industrial Press

[2] Anagbogu, P.N., Mbah, B.M \& Eme, C.A. (2010). Introduction to Linguistics.

[3] Awka, Nigeria: Amaka Dreams.

[4] Finegan, E. (2004). Language: its Structure and Use. Boston: Thomson Wadsworth.

[5] Fromkin, V. (2003). An Introduction to Language. Boston: Thomson Wadsworth.

[6] Boeckx, C \& Fumikazu, N (2004). "Conditions on Agreement in Japanese".

[7] Natural Language and Linguistic Theory. 22(3), 453-480

[8] http://en.wiktionary.org/wiki/circumfing\#English. 1/2/2011. Retrieved 12/9/2011

[9] http://www.sil.org/linguistics/glossary of linguistic terms/what is a circumfix.htm 2004.Retrieved 12/9/2011 
[10] Ihezuonu, G.C. (2011). "Mgbakwụnye Ndịna Gburugburu”. A Paper Presented in the Doctoral Seminar Series, Department of Igbo, African and Asian Studies, Nnamdi Azikiwe University, Awka Kayne, R.S. (1994). The Antisymmetry of Syntax. Massachusets: MIT

[11] Mbah, B.M. (1999). Studies in Syntax: Igbo Phrase Structure. Nsukka, Nigeria: Prize Publishers

[12] Ndimele, O.M. (1999). Morphology and Syntax. Port Harcourt; Nigeria: Emhai Printing Press

[13] Nida, (1949). Morphology: The Descriptive Analysis of Words. Ann Arbor: The University of Michigan Press Nwachukwu, P.A. (1983). Readings on the Igbo Verb. Onitsha: Africana-FEP Publishers.

[14] Okeke, C.O. (2008). "History of Morphology". In B.M. Mbah \& E.E. Mbah (eds.).

[15] History of Linguistics and Communication: A Festschrift in Honour of Professor P.A. Nwachukwu. 96-121. Enugu, Nigeria: Paschal Communications.

[16] Scalise, S. (1984). Generative Morphology. Dordrecht: Foris Schultink, H. (1987). "Discontinuity and Multiple Branching in Morphology". In C. Dotson-Smith and H. Schultink (eds.). Aspects of Language Studies in Honour of Mario Alinei (Vol. 11), 480-491 Spencer, A. (1991). Morphological Theory. Oxford: Blackwell retrieved from http://www.glottapedia.de/index.phx/circumfix, 12/9/2011

[17] Uchechukwu, C. (2011). Igbo Verb and Cognitive Linguistics. Igbo Language Studies Series 3.

[18] www.sil.org/linguistics 5/1/2004. retrieved 22/9/2011

[19] Zwicky, A.M. (1985). "Heads". Journal of Linguistics. Vol. 21.1 Zwicky, A.M. (1986). "Incorporating the Insights of Autolexical Syntax". Ohio State University Working Papers in Linguistics 